University of Nebraska - Lincoln

DigitalCommons@University of Nebraska - Lincoln

U.S. Environmental Protection Agency Papers

U.S. Environmental Protection Agency

2005

\title{
Relationship of stream flow regime in the western Lake Superior basin to watershed type characteristics
}

N. E. Detenbeck

US Environmental Protection Agency

V. J. Brady

University of Minnesota Duluth, Duluth, MN

D. L. Taylor

US Environmental Protection Agency

V. M. Snarski

US Environmental Protection Agency

S. L. Batterman

US Environmental Protection Agency

Follow this and additional works at: https://digitalcommons.unl.edu/usepapapers

Part of the Civil and Environmental Engineering Commons

Detenbeck, N. E.; Brady, V. J.; Taylor, D. L.; Snarski, V. M.; and Batterman, S. L., "Relationship of stream flow regime in the western Lake Superior basin to watershed type characteristics" (2005). U.S. Environmental Protection Agency Papers. 4.

https://digitalcommons.unl.edu/usepapapers/4

This Article is brought to you for free and open access by the U.S. Environmental Protection Agency at DigitalCommons@University of Nebraska - Lincoln. It has been accepted for inclusion in U.S. Environmental Protection Agency Papers by an authorized administrator of DigitalCommons@University of Nebraska - Lincoln. 


\section{Journal \\ of \\ Hydrology}

www.elsevier.com/locate/jhydrol

\title{
Relationship of stream flow regime in the western Lake Superior basin to watershed type characteristics
}

\author{
N.E. Detenbeck* ${ }^{*}$ V.J. Brady ${ }^{1}$, D.L. Taylor, V.M. Snarski, S.L. Batterman \\ Mid-Continent Ecology Division, National Health and Environmental Research Laboratory, US Environmental Protection Agency, \\ Office of Research and Development, 6201 Congdon Boulevard, Duluth, MN 55804, USA
}

Received 22 August 2003; revised 29 November 2004; accepted 30 November 2004

\begin{abstract}
To test a conceptual model of non-linear response of hydrologic regimes to watershed characteristics, we selected 48 secondand third-order study sites on the North and South Shores of western Lake Superior, MN (USA) using a random-stratified design based on hydrogeomorphic region, fraction mature forest, and fraction watershed storage (lake + wetland area/watershed area). We calculated several commonly used hydrologic indices from discharge and velocity estimates, including daily flow indices, overall flood indices, low flow variables, and ratios or ranges of flow percentiles reflecting the nature of cumulative frequency distributions. Four principal components (PCs) explained 85.9 and $88.6 \%$ of the variation of flow metrics among second- and third-order stream sites, respectively. Axes of variation corresponded to a runoff vs. baseflow axis, flow variability, mean flow, and contrasts between flood duration and frequency. Analysis of velocity metrics for third-order streams yielded four PCs corresponding to mean or maximum velocity, Froude number, and inferred shear velocity, as well as spate frequencies vs. intervals associated with different velocity ranges.

Using discriminant function analysis, we could discriminate among watershed classes based on region, mature forest, or watershed storage as a function of flow metrics. For second-order streams, median flow $\left(Q \mathrm{~s}_{50}\right)$ increased as watershed storage increased. North Shore streams showed a more skewed distribution and greater spread of discharge values than did South Shore streams for both stream orders, while third-order North Shore streams exhibited a higher frequency of spates. Independent of regional differences, loss of mature forest increased the range of variation between baseflow and peak flows, and depressed baseflow. Consistent with our initial model for watershed classification, Classification and Regression Tree (CART) analysis confirmed significant thresholds of change in flow metrics averaging between 0.506 and 0.636 for fraction mature forest and between 0.180 and 0.258 for fraction watershed storage.
\end{abstract}

(c) 2005 Elsevier B.V. All rights reserved.

Keywords: Flow regime; Classification; Lake Superior; Streams

\footnotetext{
* Corresponding author. Tel.: +1 218529 5204; fax: +12185295003.

E-mail address: detenbeck.naomi@epa.gov (N.E. Detenbeck).

${ }^{1}$ Present address: Natural Resources Research Institute, University of Minnesota Duluth, Duluth, MN 55811, USA.
} 


\section{Introduction}

Stream flow is one of the primary factors structuring aquatic communities, and has been used as the basis for classification systems both to describe variation in community reference condition (Poff and Ward, 1989; Biggs et al., 1998a,b; Clausen and Biggs, 1997, 2000) and to predict sensitivity to stressors or resilience of populations following disturbance (Poff, 1997; Detenbeck et al., 2000). Numerous flow metrics have been developed to describe variation in flow regimes (Poff and Ward, 1989; Clausen and Biggs, 1997, 2000). Poff and Ward (1989) categorized flow regimes across the United States into nine types, arranging these in a conceptual model along axes related to flow intermittency, flow variability, and flow predictability. In order for a flow classification scheme to be useful, we must be able not only to categorize streams and rivers based on flow regimes using existing gauge data (Poff and Ward, 1989), but also to predict flow regimes in ungauged watersheds as a function of watershed characteristics (Jennings et al., 1993; Smakhtin, 2001). If communities change gradually along a continuum of flow metrics, and if flow regimes change gradually along gradients of landscape variation, then imposition of a categorical structure to describe flow regimes or landscape regions or attributes related to flow regimes will be artificial. In this case, classification may serve a useful management purpose, but determination of boundaries of classes will be arbitrary (Hawkins et al., 2000). Conversely, if flow metrics or ecological responses to flow metrics change in a non-linear fashion, then distinct thresholds for flow regimes and watershed or regional attributes can be established to delineate class boundaries, variation in selective forces, and community responses.

The United States Geological Survey (USGS) has defined a series of empirical non-linear equations relating catchment properties such as catchment area, channel slope, catchment storage, and land-use (percent forested, percent urbanisation or percent impervious surface area) to peak flows of given recurrence intervals $\left(Q_{2}, Q_{5}, \ldots, Q_{100}\right.$; Jennings et al., 1993). Peak flows increase exponentially as catchment storage decreases below a given threshold. For northwestern Wisconsin and northeastern Minnesota, the critical thresholds appear to be between 5 and $10 \%$ catchment storage (Krug et al., 1992; Jacques and Lorenz, 1988). A second threshold, this one for peak snowmelt discharge, has been predicted to occur after $50-60 \%$ of a catchment has been logged within the last 15 years (Verry, 1986).

We designed a study to predict sensitivity of secondand third-order streams to land-use change based on the non-linear responses of hydrologic regimes to watershed attributes (Jennings et al., 1993; Richards, 1990). We selected study streams from two hydrogeomorphic regions and from within high and low classes of watershed storage and mature forest cover (based on the previously defined thresholds) to examine the interaction among these factors in determining stream sensitivity to land-use activities, as moderated by hydrology. We examined hydrologic thresholds related to (1) natural variation or altered levels of catchment storage, defined as the fraction of catchment area covered by lakes and wetlands; and (2) land-use activities affecting runoff. We define a hydrologic threshold as a breakpoint or inflection point in a nonlinear relationship between a catchment property and hydrologic response variable such as peak flows.

In our analysis of discharge data from the study, we examine two issues:

(1) Can landscape attributes explain significant variation in a suite of ecologically relevant flow metrics?

(2) Can we determine threshold changes in flow metrics in response to changes in watershed attributes of land-use and catchment storage?

Our analysis differs from earlier studies in that we have a large number of sites to examine $(n=48)$ within a single ecoregion, but only a short period of record for each site (one full growing season). This situation is not ideal given the high interannual variability of many high flow metrics (Gan et al., 1991; Clausen and Biggs, 2000), but it is typical of the type of discharge information available for most biological monitoring programs in the US.

\section{Study area}

We designed the study to compare responses across two different hydrogeomorphic regions located 
on the North Shore and South Shore of Lake Superior. Our target population included second- and thirdorder watersheds overlapping with the North Shore (Hydrologic cataloging units [HUCs] 4010101 and 4010102; Seaber et al., 1987) and the South Shore (HUC 4010301) of the western arm of Lake Superior. North Shore watersheds were located predominantly within the North Shore Highlands (NSH) while South Shore watersheds were located predominantly within the Lake Superior Clay Plain (LSCP) Ecological Units, as defined by Keys et al. (1995). Study watersheds also overlapped with the Mille Lacs Uplands and Bayfield Sand Plains Ecological Units on the South Shore. We refer to the two hydrogeomorphic regions of interest as North and South Shore regions. All of these Ecological Units are contained within the single Northern Lakes and Forest Ecoregion (Omernik and Gallant, 1988; Fig. 1). The study area is described in greater detail in Detenbeck et al. (2003).

\section{Methods}

We assessed two hydrologically based thresholds of impairment, one for watershed storage $(>10 \%$ watershed covered by lakes and wetlands) and one for mature forest $(<50 \%$ of watershed in mature forest cover) across two different hydrogeomorphic (HGM) regions corresponding to the North and South Shores of the western arm of Lake Superior. In 1997-1998 (second-order streams) and 1998-1999 (third-order streams), we randomly selected 24 watersheds in high and low mature forest classes along gradients of watershed storage within each hydrogeomorphic (HGM) region through a random-stratified process (Detenbeck et al., 2003, 2004; Table 1). Reaches were selected that had in-stream physical habitat, bank vegetation, and land-use characteristics typical of the stream segment/watershed of interest so that results might apply more broadly than to the specific reach sampled. We inspected the entire reach before sampling to confirm uniformity of conditions. Where sampling reaches were immediately adjacent to road crossings and landowner permission allowed, we selected reaches upstream from the crossing. We avoided stream reaches containing permanent tributaries or hydraulic controls (e.g. dams, bridge abutments, waterfalls) within 10 mean stream widths (Simonson et al., 1994).

\subsection{Derivation of stage-discharge rating curves}

During most of the ice-free period, stream stage was continuously monitored and logged at hourly intervals using Shallow Water Level Recorders from Remote Data Systems (C). Stage was converted to estimates of stream discharge and velocity using Manning's equation, measured channel slope and morphometry, and estimated roughness coefficients (Fetter, 1988). Discharge and velocity also were measured directly at all 48 sites during routine sampling visits but the range of values obtained were not adequate to establish good stage-discharge relationships at all sites. However, estimated roughness coefficients from the literature were not significantly different from those values that could be back-calculated using Manning's equation and discharge values measured at the sites $(p>0.05)$. Equations for stage-discharge rating curves were fitted with power or exponential curves using SlideWrite curve-fitting routines (Advanced Graphics Software, Inc., 1999). We estimated missing values for stream discharge through regression analyses, pairing data from nearby streams and when possible, sites from within the same region by watershed class. Daily discharge values were missing from an average of $20 \%$ of observations for the ice-free season of 1998 and from an average of $13 \%$ of observations for the ice-free season of 1999.

\subsection{Calculation of flow metrics}

We calculated several commonly used hydrologic indices from daily discharge and velocity averages over a period of record corresponding to the growing season (April 9-October 26, 1998; April 26-October 29, 1999), including daily flow indices (mean, median, coefficient of variation, skewness); overall flood indices (flood flow index, constancy, $Q_{90}$ ); flood frequency, magnitude, duration, and timing for floods of various levels relative to median discharge; low flow variables ( $Q_{10}$, mean annual daily minimum); and ratios or ranges of flow percentiles reflecting the nature of the cumulative frequency distribution (Poff and Ward, 1989; Richards, 1990; Poff, 1992; 

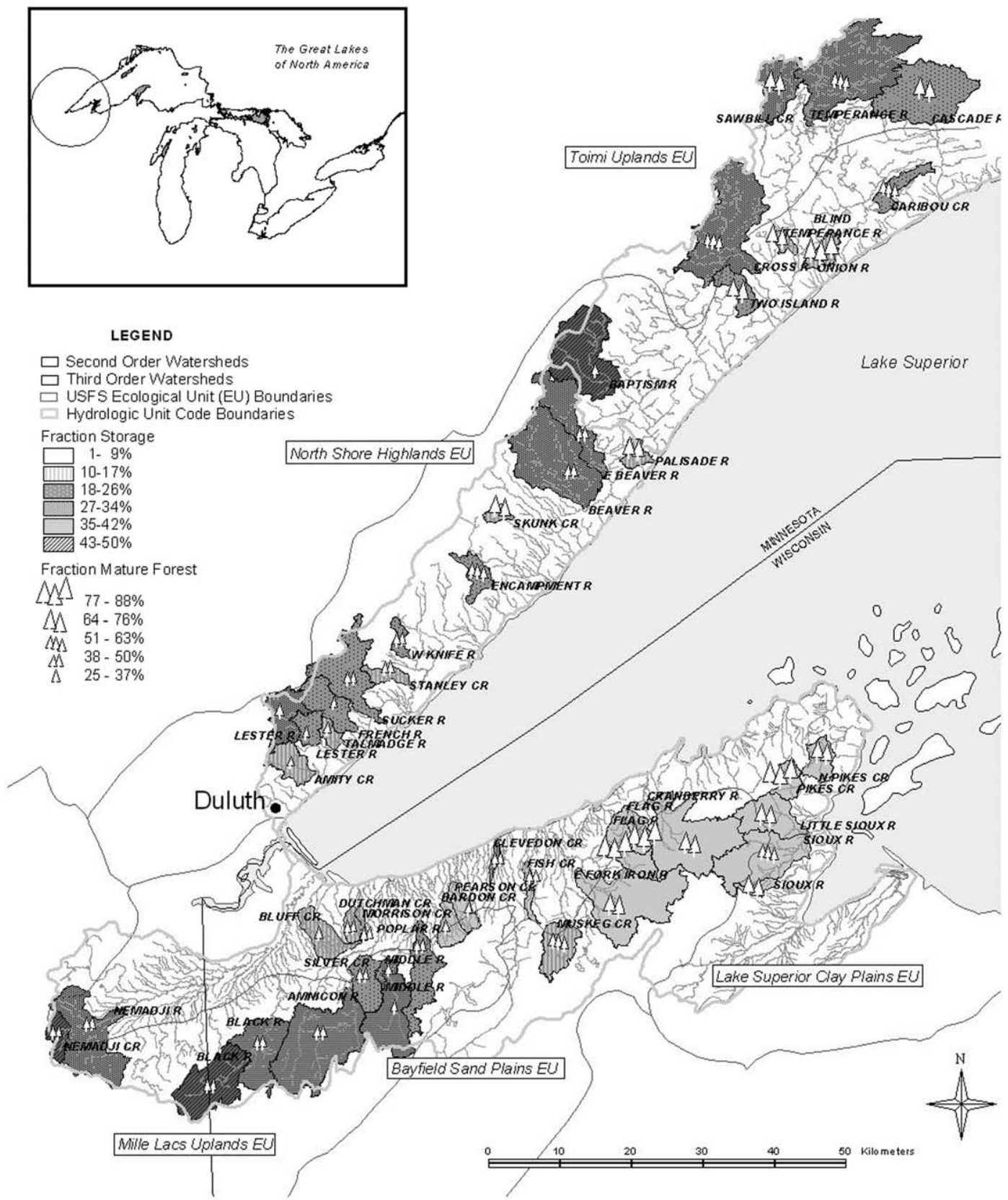

Fig. 1. Watersheds of 48 second- and third-order streams in western Lake Superior basin evaluated for flow regime.

Poff and Allan, 1995; Clausen and Biggs, 1997; Appendix 1). Unlike other studies, we were not able to calculate discharge predictability because of our short period of record (Gan et al., 1991). Most of the variables we used were normalized by dividing by the median daily flow to make metrics scaleindependent, and more readily comparable across streams (Poff and Ward, 1989). Constancy values 
Median and range of important watershed attributes for study sites surrounding western arm of Lake Superior

\begin{tabular}{lllll}
\hline & Median (range) & & & \\
\cline { 2 - 5 } & $\begin{array}{l}\text { North shore, } \\
\text { second-order }(n=12)\end{array}$ & $\begin{array}{l}\text { South shore, } \\
\text { second-order }(n=12)\end{array}$ & $\begin{array}{l}\text { North shore, } \\
\text { third-order }(n=10)\end{array}$ & $\begin{array}{l}\text { South shore, } \\
\text { third-order }(n=14)\end{array}$ \\
\hline Area (ha) & $2000(1000-7300)$ & $2400(670-9700)$ & $11,000(2900-20,000)$ & $8300(2200-17,000)$ \\
Fraction storage & $0.15(0.10-0.34)$ & $0.13(0.01-0.50)$ & $0.27(0.24-0.44)$ & $0.10(0.01-0.42)$ \\
Fraction mature forest & $0.48(0.26-0.81)$ & $0.43(0.36-0.88)$ & $0.51(0.25-0.69)$ & $0.46(0.27-0.81)$ \\
\hline
\end{tabular}

were calculated by summing across 10 flow intervals (Poff and Ward, 1989):

$C=\sum_{i=1}^{10} \log _{\mathrm{e}}\left(\left(\right.\right.$ mean daily flow $\left.\left.{ }_{i}+1\right) / Q \mathrm{~s}_{\text {mean }}\right)$

In addition, we tested several previously unassessed velocity metrics that we expected to be related to shear stress: (1) mean daily Froude number $(F r)$ during baseflow periods, (2) average peak Froude number during floods, (3) mean daily Inferred Shear Velocity $\left(\mu^{*}\right)$ during baseflow periods, and (4) average peak Inferred Shear Velocity during floods (Quinn and Hickey, 1994). The Froude number ( $F r)$ is used by hydraulic engineers to describe types of flow.

$F r$ can be thought of as the ratio of kinetic energy (proportional to velocity) to potential energy (proportional to acceleration due to gravity $\times$ hydraulic depth). $F r$ values greater than 1 describe supercritical flow; $F r$ values less than 1 describe subcritical or tranquil flow. $F r$ values for pools were less than 0.18 , while $\mathrm{Fr}$ values for riffles were greater than 0.41 across 1112 stream sites in New Zealand (Jowett, 1993). Froude number has been related to fish and macroinvertebrate distribution patterns (Statzner and Higler, 1986; Heede and Rinne, 1990). The probability of stream bed particle movement has also been correlated with invertebrate community structure and composition (Cobb et al., 1992). Sediment stability is a function of stream substrate size, water depth, and channel slope. A critical shear stress (tractive force) can be determined that must be surpassed in order for sediments of a given size to be mobilized; thus inferred shear velocity is used as an indicator of the probability of sediment disturbance. Froude number and inferred shear velocity were calculated based on conditions in stream riffles where macroinvertebrate samples were collected. Finally, we selected velocity metrics likely to have an effect on periphyton, i.e. baseflow velocity (likely to produce nutrient stimulation for selected growth forms; Biggs et al., 1998a,b), maximum peak velocity during growing season and average peak velocity during storms across the growing season (an indicator of the potential for sloughing), and the median spate interval and frequency for different magnitudes (all spates, $10-20,20-50,50-80$, and $>80 \mathrm{~cm} / \mathrm{s}$ ).

\subsection{Statistical analyses}

Before performing any statistical analyses, we transformed flow and velocity metrics where necessary to achieve univariate normality using Box-Cox transformations (SAS, 1990); we then checked the resultant data set for multivariate normality using chi-square plots (SAS, 1991). Data for second- and third-order streams were analyzed separately because of strong differences in magnitude and frequency of precipitation between study years.

Using Mantel's test in PC-ORD (McCune and Mefford, 1999), we analyzed potential associations between climatic variables and landscape variables that might confound interpretation of effects of hydrogeomorphic region, storage, and mature forest effects on flow regimes. Mantel's test is a nonparametric procedure to examine relationships between two or more distance matrices (Sokal and Rohlf, 1995); in this case we used Euclidean distance. The value or class for each landscape variable (region, storage or mature forest) was compared with watershed values for annual snowfall, growing season precipitation (April-October), and number of growing season days with rainfall exceeding 1 in. Study watershed values for climatic variables were derived from climatic summaries from regional weather stations for the years 1971-2000 (Wisconsin State Climatology Office; Minnesota State Climatology Office). Using Thiessen polygon 
methods in the AREAL_RAIN extension of ArcView (CESRI, Redlands, CA; Petras, 2001), we assigned weighting factors for each set of weather station variables to each study watershed.

To reduce dimensionality to a few major axes of variation and to determine which metrics were redundant, we applied principal component analysis with varimax rotation to the correlation matrix of flow variables (SAS, 1990). It is more appropriate to use correlation matrices for PCA than covariance matrices when variables are expressed in different units or have dramatically different ranges. For PC analysis, the number of independent variables must be less than the number of observations (sites); the number of input variables was reduced as follows. For PC analysis, we preferentially included metrics for more extreme events where available (e.g. $3 \times$ median flow), but excluded variables for which there were any missing values due to zero denominators or non-occurence of a given event magnitude (final subsets selected are indicated in Appendix 1).

We tested the ability of our watershed classification factors (hydrogeomorphic region, watershed storage, mature forest) to explain variation in a subset of flow metrics through analysis of covariance (ANCOVA) techniques (PROC GLM; SAS, 1990). To limit the number of occurrences of Type I errors, analysis of flow regime metric differences among watershed classes was limited to a few key variables, i.e. those expected to be correlated with loading of non-point source pollutants or baseflow, and those found to be most significant in explaining differences in fish community composition across Minnesota and Wisconsin (Poff and Ward, 1989). In ANCOVA tests for watershed attribute effects on flow regimes of second-order streams, we had to remove values for two streams from the data set to meet model assumptions. These streams had relatively small watersheds entirely within the Lake Superior Clay Plain, and baseflow was reduced to zero during much of the growing season. Zero in the denominator of several of the flow metrics for these systems had to be replaced with minimum detectable discharge values. A beaver dam constructed downstream of the study reach for Muskeg Creek in 1998 precluded us from developing stage-discharge relationships in the normal fashion; therefore, we only used values for Muskeg Creek for the mean annual minimum flow corrected for watershed area $\left(\mathrm{MAM}_{\text {corr }}\right)$, and PFI, the ratio of estimated bankfull discharge to baseflow.

To determine which flow or velocity metrics could be used to distinguish among watershed classes, we applied discriminant function analyses. Watershed classes were examined by region, mature forest, or watershed storage categories alone and in combination. After applying stepwise discriminant analysis to narrow down the range of explanatory flow or velocity metrics, we used PROC DISCRIM within SAS on the selected subset of metrics to define linear discriminant functions to assign observations to different groups. Classification error rates were estimated using the CROSSVALIDATE option. Low error rates indicate that flow metrics are distinct among groups.

Finally, we assessed the nature of the response of flow and velocity PC scores to region, percent mature forest, and catchment storage. We identified potential discontinuities (thresholds) of response through Classification And Regression Tree analysis (CART; Wilkinson, 1999), using variables related to watershed classes as potential predictor variables and the principal component scores for velocity and flow metrics as the response variables. CART builds classification and regression trees for predicting continuous-dependent variables (regression) and categorical predictor variables (classification). The purpose of the analyses via tree-building algorithms is to determine a set of if-then logical (split) conditions that permit accurate prediction or classification of cases. The results have the advantage of being intuitively simple and there is no implicit assumption that the underlying relationships between the predictor variables and the dependent variable are linear, follow some specific non-linear function, or that they are even monotonic in nature (Breiman et al., 1984).

\section{Results}

\subsection{Interannual differences in precipitation}

Differences in flow or velocity metrics between second- and third-order streams could have been influenced by differences in weather between years. The maximum snowpack over the winter of 
1996-1997 was above average, over $100 \mathrm{~cm}$ in depth, as compared to a below-average maximum snowpack of 46-50 cm over the winters of 1997-1998 and 1998-1999 (Midwest Climate Center, 2000). We installed shallow-water level recorders in secondorder streams in early- to mid-July in 1997, just after a major summer storm event of $7 \mathrm{~cm}$ recorded at the Duluth airport, but subsequent major rainfall events over the growing seasons of 1997 and 1998 were relatively infrequent. The cumulative annual rainfall recorded for 1997 was only $53 \mathrm{~cm}$ at the Duluth airport, well below the long-range North and South Shore averages of 71 and $78.7 \mathrm{~cm}$, respectively. Precipitation during the period of monitoring for third-order streams was either just above average (cumulative annual rainfall, $80.1 \mathrm{~cm}$ for 1998) or well above average (cumulative annual rainfall, $96.8 \mathrm{~cm}$ for 1999). Rainfall events during the growing season of 1999 were frequent and substantial, with two events of $>8 \mathrm{~cm} /$ day recorded at the Duluth airport (Midwest Climate Center, 2000).

\subsection{Associations between climatic and landscape variables}

Two of the nine Mantel tests conducted were significant at a $p$-value of $0.05 / 9=0.0056$. A higher number of growing season days with greater than 1 in. precipitation occurred in South Shore watersheds as compared to North Shore watersheds (Mantel's standardized $r=0.237, p=0.001, n=47)$. Total growing season precipitation was positively associated with fraction mature forest in watersheds (Mantel's standardized $r=0.427, p=0.001, n=47$ ), but the number of high precipitation days was not.

\subsection{Correlation structure of flow and velocity metrics}

All principal components with an eigenvalue greater than 1.0 were retained. The first four principal components based on PCA of flow metrics from second-order streams explained $85.9 \%$ of the variation among sites, with the first PC explaining 52.3\%. Most flow metrics were well-represented by these four PCs; only the flow coefficient of variation (CVLF5) and $2 \times$ median flow peak (PEA2COR) metrics had less than $70 \%$ of their variance (11 and 65\%) described by these PCs. The first PC represented a contrast between flashy sites (high measures of spread [R10R90], high magnitude, duration, and frequency of peak flows [QS90COR, VOL3COR, DUR3, FRE3, FRE2]), and those with high baseflow (QS10COR, MAMCORR; Table 2). PC2 was highly correlated with mean or median flow. PC3 was moderately correlated with coefficient of variation of daily flow, but negatively with measures of spread (SPT6S). PC4 was moderately correlated with spread (SPT8S).

Principal component analysis of flow metrics from third-order streams yielded similar results, particularly for PC1. The first four principal components explained $88.6 \%$ of the variation among sites, with the first PC explaining $62.3 \%$ of the variance. PC1, which we define as the groundwater-runoff axis, separated sites with relatively high peak flows and flashy flow regimes (high flood indices, peak flow, measures of spread, daily variation) from those with high baseflow (Table 2). PC2 separated sites based on magnitude and frequency of large events (FRE3, PEA3COR) vs. duration of flows above $1.1 \times$ median. PC3 arranged sites along a gradient of mean or median flow.

PCA of second-order velocity metrics yielded four PCs explaining $80 \%$ of the variance among sites. PC1 (average velocity) had strong positive correlations with baseflow or median Froude number, and most summary statistics for inferred shear velocity; and moderate negative correlations with maximum velocity (Table 3). PC2 (spate frequency) was most strongly correlated with frequencies of spates (10-20, $20-50,50-80 \mathrm{~cm} / \mathrm{s}$ ). PC3 showed moderate negative correlations with frequency of high velocity spates $(>80 \mathrm{~cm} / \mathrm{s})$ and moderate positive correlations with average or median Froude number during spates. PC4 (baseflow) represented a moderate contrast between mean baseflow Inferred Shear Velocity and the median interval between all spates $>10 \mathrm{~cm} / \mathrm{s}$.

PCA for velocity metrics with third-order streams also yielded PCs representing overall stream power and baseflow velocity, but results differed in showing separation of streams with characteristic spate velocities. The first four PCs explained $85.6 \%$ of variance among streams. PC1 (overall stream power) was strongly positively correlated with all summary statistics for Froude number and velocity, both baseflow and peak conditions, and frequency of spates $>50$ or $>80 \mathrm{~cm} / \mathrm{s}$; and negatively correlated with average baseflow or peak inferred shear velocity 
Table 2

Significant correlations $(p<0.05)$ between principal components and original flow metrics for second-order streams and for third-order streams in western Lake Superior basin

\begin{tabular}{|c|c|c|c|c|c|c|c|c|}
\hline \multirow[t]{2}{*}{ Flow metrics } & \multicolumn{4}{|c|}{ Second-order streams } & \multicolumn{4}{|c|}{ Third-order streams } \\
\hline & PC1 & $\mathrm{PC} 2$ & PC3 & $\mathrm{PC} 4$ & PC1 & $\mathrm{PC} 2$ & PC3 & $\mathrm{PC} 4$ \\
\hline $\mathrm{CON}(-, \mathrm{B})$ & 0.88 & & & & 0.95 & & & \\
\hline CVLF5 (B) & & & & & & & 0.51 & \\
\hline DUR1P1 & - & - & - & - & 0.45 & -0.42 & & 0.71 \\
\hline DUR3 & 0.85 & & & & - & - & - & - \\
\hline FFI (L) & 0.88 & & & & 0.89 & & & \\
\hline FRE2 & 0.89 & & & & - & - & - & - \\
\hline FRE3 $(A, B)$ & 0.89 & & & & 0.48 & 0.78 & & \\
\hline LQSMEAN & -0.48 & 0.81 & & & -0.6 & & 0.74 & - \\
\hline MAMCORR & -0.84 & & & & - & - & - & - \\
\hline PEA2COR (B) & 0.59 & 0.52 & & & - & - & - & - \\
\hline PEA3COR (L) & - & - & - & - & 0.69 & 0.68 & & \\
\hline PFI (B) & - & - & - & - & 0.58 & -0.45 & & \\
\hline QPERARE (L) & & 0.87 & & & -0.44 & & 0.75 & \\
\hline QS10COR (B) & -0.87 & & & & - & - & - & - \\
\hline QS50 (B,L) & & 0.81 & & 0.46 & -0.77 & & 0.58 & \\
\hline QS90COR (B) & 0.88 & & & & 0.94 & & & \\
\hline QSCV $(\mathrm{L},-)$ & 0.82 & & 0.46 & & 0.76 & 0.47 & & \\
\hline QSK (B) & 0.9 & & & & 0.82 & 0.49 & & \\
\hline QSMEAN $(\mathrm{B}, \mathrm{L})$ & & 0.88 & & & & & & \\
\hline R10R90 (B) & 0.82 & & -0.47 & & 0.9 & & & \\
\hline R20R80 (B) & - & - & - & - & 0.91 & & & \\
\hline R25R75 (B) & - & - & - & - & 0.9 & & & \\
\hline SPT5S (L) & 0.86 & & & & 0.93 & & & \\
\hline SPT6S (B,L) & & & -0.94 & & 0.95 & & & \\
\hline SPT8S $(-, L)$ & 0.49 & -0.49 & & 0.64 & 0.98 & & & \\
\hline TIM1P1 & - & - & - & - & 0.77 & & 0.44 & \\
\hline TIM3 (L) & 0.88 & & & & - & - & - & - \\
\hline VOL3COR (L) & 0.88 & & & & 0.85 & 0.42 & & \\
\hline
\end{tabular}

A, L or B denote transformation to achieve normality using arcsin(square root), $\log 10$ or Box-Cox, respectively. See Appendix 1 for metric definitions (-, dropped from this analysis).

and with frequency of small spates $(10-20 \mathrm{~cm} / \mathrm{s}$; Table 3). PC2 (weak spates) represented a contrast between base inferred shear velocity and duration of weak spates vs. the interval between weak spates $(10-20 \mathrm{~cm} / \mathrm{s})$. PC3 (moderate spates) represented a contrast between frequency and interval between moderate spates $(20-50 \mathrm{~cm} / \mathrm{s})$. PC4 (strong spates) represented a contrast between median interval and frequency of large spates $(50-80 \mathrm{~cm} / \mathrm{s})$.

\subsection{Watershed class differences in flow regime}

Subsets of flow variables which best discriminated among watersheds classified by region and mature forest were different for second vs. third-order streams, but subsets predicting storage class overlapped between stream orders (Tables 4 and 5). For second-order streams, a coefficient of skewness, peak flows, and flood volumes best distinguished between regions; while for third-order streams, frequency of $2 \times Q s_{50}$ events was the only variable that distinguished between regions. For second-order streams, no combination of flow variables significantly discriminated among mature forest classes overall, although for North Shore streams, baseflow (MAMCORR) did discriminate between mature forest classes. For third-order streams, flow variability and frequency or duration of peak flows distinguished between mature forest classes overall, and within mature forest $\times$ region classes. For both second- and third-order streams, a large combination of flow variables discriminated between storage classes, 
Table 3

Significant correlations $(p<0.05)$ between principal components and original velocity metrics for second-order streams and for third-order streams in western Lake Superior basin

\begin{tabular}{|c|c|c|c|c|c|c|c|c|}
\hline \multirow[t]{2}{*}{ Velocity metrics } & \multicolumn{4}{|c|}{ Second-order streams } & \multicolumn{4}{|c|}{ Third-order streams } \\
\hline & PC1 & $\mathrm{PC} 2$ & PC3 & $\mathrm{PC} 4$ & PC1 & $\mathrm{PC} 2$ & $\mathrm{PC} 3$ & $\mathrm{PC} 4$ \\
\hline BASEVEL (L) & -0.56 & 0.53 & 0.51 & & 0.94 & & & \\
\hline FRAVPK (L) & 0.79 & & 0.46 & & 0.98 & & & \\
\hline FRBASE (L) & 0.80 & -0.43 & & & 0.90 & & & \\
\hline FRESPAT (B) & & 0.43 & & & & 0.45 & 0.53 & \\
\hline FRMDPK (L) & 0.80 & & 0.42 & & 0.97 & & & \\
\hline FRMXPK (L) & 0.77 & & & & 0.96 & & & \\
\hline FSP1020 (B) & & 0.79 & & & -0.77 & & & \\
\hline FSP2050 & -0.50 & 0.63 & & & & -0.86 & & \\
\hline FSP5080 (L) & & 0.62 & -0.48 & & 0.75 & & & -0.43 \\
\hline FSPGT80 (L) & 0.55 & & -0.58 & & 0.79 & & & \\
\hline ISVAVPK (B) & 0.89 & & & & -0.89 & & & \\
\hline ISVBASE (B) & 0.66 & & & -0.56 & -0.77 & & 0.46 & \\
\hline ISVMDPK (L) & 0.88 & & & & 0.95 & & & \\
\hline ISVMXPK & 0.83 & 0.42 & & & 0.86 & & & \\
\hline MEDVINT (L) & 0.48 & & & 0.46 & & & & \\
\hline MIN1020 (L) & - & - & - & - & 0.78 & & & \\
\hline MIN2050 (L) & - & - & - & - & & 0.85 & & \\
\hline MIN5080 (L) & - & - & - & - & -0.77 & & & 0.52 \\
\hline MINGT80 (L) & - & - & - & - & -0.77 & & & \\
\hline PVELAVG (L) & 0.85 & & & & 0.96 & & & \\
\hline PVELMAX (L) & -0.61 & & 0.54 & & 0.93 & & & \\
\hline PVELMED (L) & 0.80 & & & & 0.96 & & & \\
\hline
\end{tabular}

L or B denote transformations to achieve normality, using $\log 10$ or Box-Cox transformation, respectively. See Appendix 1 for metric definitions (-, dropped from this analysis).

including metrics for baseflow, flow variability, constancy, and timing; duration and magnitude (peak, volume) of flood events ranging from $1.1 \times$ median to $3 \times$ median flow. This was particularly true within low mature forest classes (Table 4).

Classification strength was moderate for discrimination between regions, but differed with stream order for mature forest and storage classes. For secondorder streams, classification error rates determined by cross-validation were moderate for region (22\%) and mature forest classes (17\% for North Shore) but high for storage classes (38\% overall, $50-55 \%$ within region or mature forest class). For third-order flow metrics, classification error rates were moderate for region (28\%), low to moderate for mature forest class (29\% overall, $0 \%$ for NS, $21 \%$ for SS), and below detection $(0 \%)$ for storage overall.

Of those flow metrics tested by ANCOVA for second-order streams, median flow $\left(Q \mathrm{~s}_{50}\right)$ was the only variable significantly affected by watershed storage, increasing as watershed storage increased $(p<0.05)$. North Shore streams had a more skewed distribution of discharge values and greater spread in the distribution as compared to South Shore streams $(p<0.05)$. The flood flow index (flood flow/baseflow, FFI) was significantly affected by a region by mature forest interaction when two outliers were dropped $(p<0.05)$. Prior to dropping these outliers, the flood flow index was significantly affected by region only, with North Shore values greater than South Shore values. With outliers removed, low mature forest watersheds on the South Shore had greater flood flow indices than high mature forest watersheds, indicating relatively greater contributions from runoff.

For third-order streams, North Shore streams had more variable hydrologic regimes, as measured by CVLF5, an index of variation among discharge percentiles, and a higher frequency of spates $(p<0.05)$. Independent of regional differences, low mature forest was associated with an increased range between baseflow and peak flows, and with depressed baseflow $(p<0.05)$. Fraction storage tended to 
Flow metrics that discriminate among watershed classes, based on discriminant function analysis

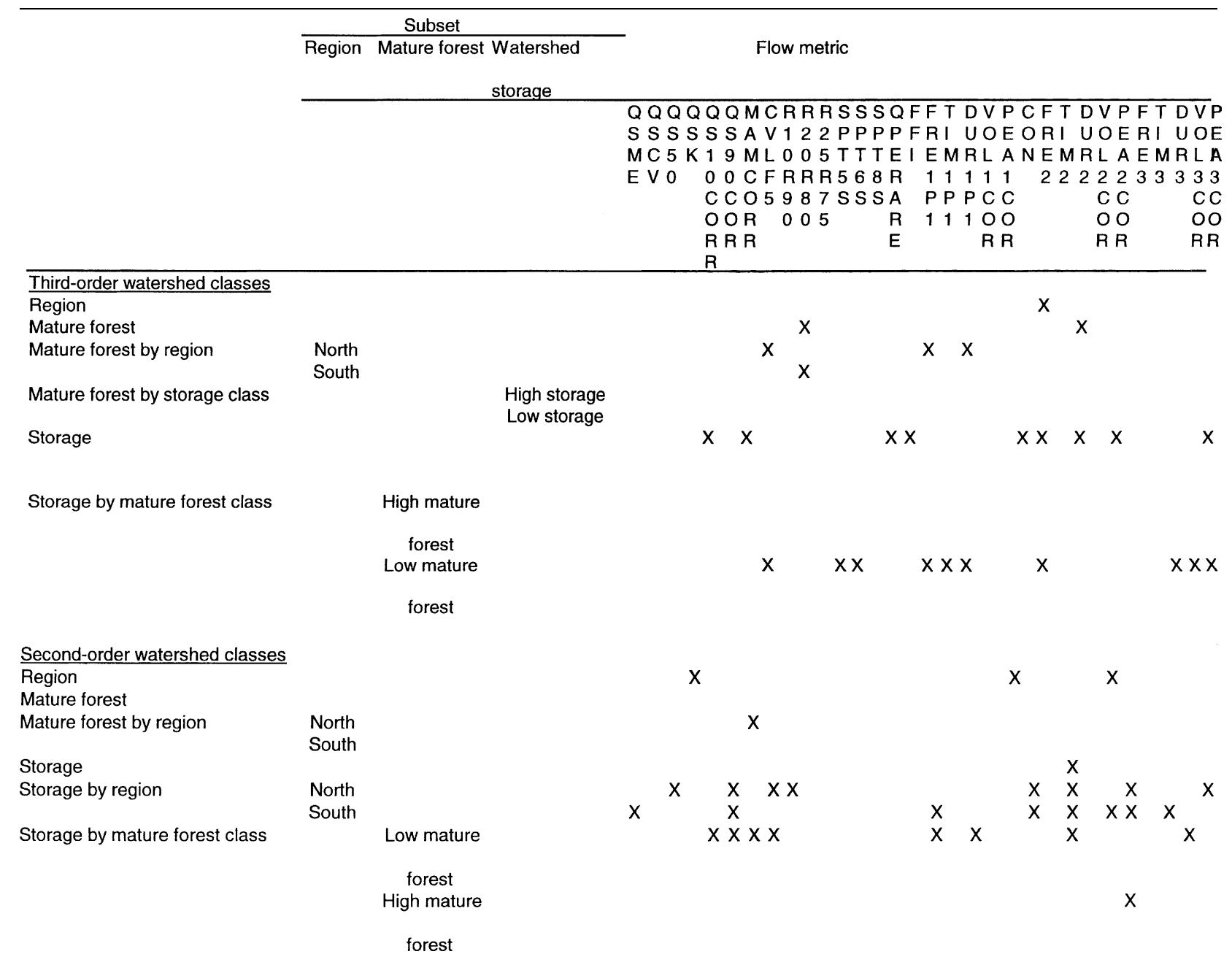

See Appendix 1 for flow metric definitions. $\mathrm{X}$ in a column indicates that a given flow metric helped to discriminate among the watershed classes defined by the variables listed in each row. Discriminant function analysis was conducted using the full data set for each of second- and third-order streams, and again within each region, mature forest class, or storage class subset, the latter to examine potential interactions. 
Table 5

Velocity metrics that discriminate among watershed classes

\begin{tabular}{|c|c|c|c|c|c|c|c|c|c|}
\hline & \multicolumn{3}{|l|}{ Subset } & \multicolumn{6}{|c|}{ Velocity metrics } \\
\hline & Region & $\begin{array}{l}\text { Mature } \\
\text { forest }\end{array}$ & Storage & ISVBASE & ISVAVPK & FREQSPA & FSPA2050 & FSPGT80 & MIN2050 \\
\hline \multicolumn{10}{|c|}{ Second-order watershed classes } \\
\hline Region & & & & & & & & $\mathrm{X}$ & \\
\hline \multicolumn{10}{|l|}{ Mature forest } \\
\hline Mature forest & & & & & $\mathrm{X}$ & & & & \\
\hline by region & $\mathrm{N}$ & & & & & & & & \\
\hline Storage & $\mathrm{S}$ & & & & & & & & \\
\hline Storage by region & $\mathrm{N}$ & & & & & & & & \\
\hline Storage by mature & $\mathrm{S}$ & LO & & & & & $\mathrm{X}$ & & \\
\hline forest class & & HI & & & & & & & \\
\hline \multicolumn{10}{|c|}{ Third-order watershed classes } \\
\hline Region & & & & & & & $\mathrm{X}$ & & \\
\hline Mature forest & & & & & & $\mathrm{X}$ & & & $\mathrm{X}$ \\
\hline Mature forest & $\mathrm{N}$ & & & & & $\mathrm{X}$ & & & $\mathrm{X}$ \\
\hline by region & $\mathrm{S}$ & & & & & & & & \\
\hline \multirow{2}{*}{$\begin{array}{l}\text { Mature forest } \\
\text { by storage class }\end{array}$} & & & $\mathrm{HI}$ & & & & & & \\
\hline & & & LO & & & & & & \\
\hline \multicolumn{10}{|l|}{ Storage } \\
\hline Storage by region & $\mathrm{S}$ & & & & & & & & \\
\hline Storage by mature & & HI & & $\mathrm{X}$ & & & $\mathrm{X}$ & & \\
\hline forest class & & LO & & & & & & & \\
\hline
\end{tabular}

ISVBASE, ISVAVPK = Inferred shear velocity during baseflow or peak flows. FREQSPA, FSPA2050, FSPGT80=frequency of spates with velocities $<10,20-50$, and $>80 \mathrm{~cm} / \mathrm{s}$. MIN2050= median interval between spates in $20-50 \mathrm{~cm} / \mathrm{s}$ range.

decrease the index of variation, CVLF5, in both regions $(p<0.05)$.

\subsection{Evidence for response thresholds}

CART analysis identified both primary and secondary thresholds for fraction mature forest and fraction watershed storage with respect to flow or velocity metrics (Table 6, Fig. 2). Lowess (smoothing) plots were used to illustrate examples of variables for which CART had identified threshold responses (Fig. 2). CART analysis iteratively divides a population of responses into two significantly different subpopulations, identifying both the best predictor variable and the magnitude of the predictor variable associated with that division. Here we associate the initial division in CART with a 'primary threshold' and subsequent divisions with a 'secondary threshold'. Fraction mature forest thresholds for flow metrics averaged between 0.506 and 0.636 , and between 0.180 and 0.258 for fraction watershed storage.

\section{Discussion}

\subsection{Correlation structure of flow and velocity metrics}

Redundancy of flow metrics appears to be greater at regional than nationwide scales, as would be expected if flow distribution parameters are consistent within regions but vary across regions. While Poff (1996) found relatively few significant correlations among different flow regime metrics calculated for streams across the United States, we found a high degree of redundancy within low-flow metrics, floodrelated metrics based on different flood threshold values, and various metrics related to flow variability, 
Table 6

Summary of thresholds in response of flow and velocity principal component (PC) scores associated with watershed classification variables (mature forest and watershed storage) identified through Classification and Regression Tree (CART) analysis

\begin{tabular}{llllllll}
\hline \multirow{2}{*}{ Response } & \multicolumn{2}{l}{ Average primary threshold value (range) } & & & \multicolumn{2}{c}{ Average secondary threshold value (range) } \\
\cline { 2 - 3 } & Stream order & Fraction mature forest & Fraction storage & & Fraction mature forest & Fraction storage \\
\hline Flow and velocity & 2 & 0.506 & 0.180 & & 0.636 & - \\
PC scores & & $0.383-0.731$ & $0.157-0.280$ & & $0.417-0.759$ & - \\
Flow and velocity & 3 & 0.539 & 0.231 & & 0.537 & 0.258 \\
PC scores & & $0.411-0.684$ & $0.020-0.375$ & & $0.363-0.639$ & $0.239-0.299$ \\
\hline
\end{tabular}

consistent with other studies conducted at a regional scale (Richards, 1990; Clausen and Biggs, 2000). High flow statistics calculated for different thresholds tended to be highly intercorrelated, with the exception of FLODFRE1, FLODDUR1, and FLODDUR3. Many measures of low-flow metrics associated with different averaging periods and return intervals are linearly related, and some can be described by a common cumulative distribution function if adjustments are made for differences in mean value (Smahtkin and Toulouse, 1998; Galea et al., 2000).

The axes of variation we identified for flow metrics at the regional scale were similar to those proposed at the continental scale (Poff and Ward, 1989; Poff and Allan, 1995; Richter et al., 1996), with the exception of flood predictability, which we could not calculate due to an inadequate period of record. Poff proposed a conceptual model for stream flow-based classification, with stream types varying along axes of intermittency, flood frequency, flood predictability, and overall flow predictability (Poff and Ward, 1989; Poff and Allan, 1995). Based on our study, we can conclude that three of these axes of variability are valid not only at the national scale, as Poff and colleagues had showed, but also at the regional scale, at least for the Northern Lakes and Forest Ecoregion.

The independent variation in spates of different magnitudes that we found suggests that processes controlled by spates of different magnitudes may also vary independently of one another. These results are unique, as few previous comparisons have been made across multiple velocity metrics among streams and stream habitat biotypes (Statzner and Higler, 1986; Wadeson and Rowntree, 1998). For example, other studies have indicated that processes such as nutrient uptake, periphyton sloughing, and invertebrate habitat disturbance are influenced by different ranges of flow velocity. Exposure to different spate magnitudes can be expected to have differential effects on various growth forms of periphyton, with lower magnitude spates stimulating growth of filamentous green algae, moderate intensity spates selecting for short-stalked diatoms, and higher intensity spates selecting for mucilagenous diatoms (Biggs et al., 1998). Spate magnitude would also be expected to have differential effects on stream invertebrates, with small spates having a stimulatory effect, and large spates reducing invertebrate abundance and diversity (Cobb et al., 1992; Clausen and Biggs, 1997).

\subsection{Regionalization of flow regimes}

The significance of different factors controlling variation in flow regimes is likely scale-dependent,

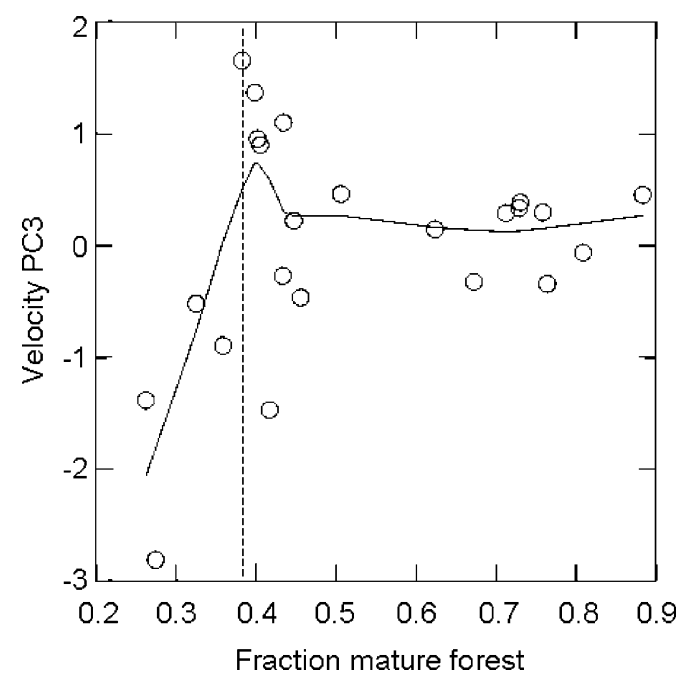

Fig. 2. Velocity principal component 3 vs. fraction mature forest, second-order streams. 
with climate, vegetation, and physiography driving variation at continental scales, and relative magnitude of different storage compartments (soil, depressional storage) driving variation at local and regional scales. Geographically coherent regions have been derived to define relationships between watershed attributes such as drainage area and low-flows or peak flows at both nationwide and state-wide scales (reviewed in Jennings et al., 1993; Smakhtin, 2001), but historically little attention has been focused on factors determining boundaries among regions. Traditionally, regionalization of low-flow and peak-flow regression equations has relied on definition of geographically coherent areas with similar magnitude and sign of residuals (Tasker, 1982). More recently, regionalization techniques have been developed that focus on both seasonality and magnitude of flood regimes, and thus reflect dominant flood-producing mechanisms (e.g. snowmelt, rain-on-snow, runoff) and weather patterns (Magilligan and Graber, 1996; Castellarin et al., 2001; Post and Jones, 2001).

Our results suggest that differences in flow distribution parameters across regions for the western arm of Lake Superior is probably a combined function of slope and soil storage components. For secondorder streams, the coefficient of skewness, peak flows, and flood volumes best distinguished between regions, while for third-order streams, frequency of $2 \times Q \mathrm{~s}_{50}$ events was the only variable that categorically distinguished between North and South Shore regions. Results of ANCOVAs were consistent with DFA results, with North Shore streams showing a more skewed distribution of discharge values and greater values for distribution spread metrics.

Runoff volume is likely to differ across North and South Shore regions mainly as a function of channel slope, which is generally greater in North Shore streams, rather than as a function of precipitation (with more frequent events in South Shore watersheds) or infiltration rates (highly variable on the South Shore; Detenbeck et al., 2003, 2004). Coefficients of skewness can vary regionally either as a function of degree of skewness in the rainfall-depth frequency distribution, or of total watershed storage. For large values of the runoff curve number $(\mathrm{CN})$ and precipitation $(P)$, discharge $(Q)$ is approximately proportional to $P$, and the skewness of the peakdischarge frequency curve depends on the degree of skewness in the 24-h rainfall-depth frequency curve (McCuen and Hromadka, 1988). However, for small values of $\mathrm{CN}$, there is a highly non-linear relationship between $P$ and $Q$ and the form of the runoff equation is the dominant factor affecting the skew of the peakdischarge frequency curve. Skew decreases as total watershed storage increases. McCuen and Hromadka's analysis of watershed storage effects included not only depression storage, but other components such as aquifer, soil moisture storage, and bank storage as well. To the extent that some South Shore watersheds overlap with coarse-grained deposits in the Bayfield Sand Plain, the watershed soil storage component is much greater than that in North Shore watersheds, which have relatively thin glacial deposits (Olcott et al., 1978).

\subsection{Factors controlling flow regime variation within regions}

Previous work relating watershed characteristics to flow regimes within regions has focused solely on peak flows and base flows. Within geographically coherent regions, analyses of geographic factors affecting baseflow have identified catchment area, mean annual precipitation, channel and/or catchment slope, stream density, \%lake area, \%forested area, soil/geology indices, length of main stream, catchment shape, watershed perimeter, mean catchment elevation, and $\%$ of catchment with northeast aspect as explanatory variables (Smakhtin, 2001). Analyses of geographic factors affecting peak flows have identified watershed area, channel slope, and watershed storage as common parameters in regional peak flow regression equations, with occasional additions of other topographic (elevation), soils (minimum permeability), or climatic (snowpack, mean or extreme monthly temperatures) variables (Jennings et al., 1993).

\subsection{Storage effects}

In our study, many different flow variables discriminated between storage classes for both second- and third-order streams, including metrics for timing, duration and magnitude (peak, volume) of high flow events ranging from $1.1 \times$ to $3 \times Q_{50}$, baseflow, flow variability, and constancy. Flow variability and flood peaks were smaller for the high 
watershed storage class. For both northwestern Wisconsin and northeastern Minnesota, peak flows have been shown to increase exponentially as depression storage decreases below a threshold value of 5-10\% watershed area (Jacques and Lorenz, 1988; Krug et al., 1992) and our results for thresholds are close to (but slightly higher than) this threshold range. Through simulations with urban stormwater models, Goforth et al. (1983) determined that detention storage had the effect of reducing both the number of events and event volume. As described above, runoff models also predict that the coefficient of skewness can be decreased by watershed storage at lower runoff coefficients and/or precipitation values (McCuen and Hromadka, 1988). In the present study, the skewness coefficient was not correlated with watershed storage but did correlate with region, indicating the influence of watershed soil storage on the South Shore.

In our study, median flow increased linearly with watershed (depression) storage. This is consistent with the structure of hydrologic models which model baseflow recession curves as outflows from multiple storage compartments within a watershed (Griffiths and Clausen, 1997; Moore, 1997).

\subsection{Mature forest effects}

Streams in high and low mature forest watersheds exhibited different types of flow. For North Shore, but not South Shore second-order streams, baseflow (MAMCORR) discriminated between mature forest classes. For third-order streams, flow variability and frequency or duration of peak flows distinguished between mature forest classes over both regions. Low mature forest was associated with an increased range between baseflow and peak flows, and depressed baseflow. Some of the difference between baseflow of mature forest class watersheds in our region could be related to the positive association between percent mature forest and growing season precipitation. However, precipitation differences between low and high mature forest classes are not consistent with the direction of observed differences in range of variation. Most studies have documented an increase in baseflow immediately following deforestation (Whitehead and Robinson, 1993), although transpiration rates can increase above those of mature forests during early stages of regeneration (Roberts, 2000). Our land-use data were not of sufficient resolution to allow us to examine the effect of time since deforestation on baseflows.

Most studies of forestry effects have examined effects on total water yield or peak flows in the first few years following harvest. In general, loss of forest cover has been associated with increased water yields, with a $10 \%$ reduction in conifer forest cover leading to a $20-25 \mathrm{~mm}$ increase in yield and a $10 \%$ reduction in deciduous hardwood forest cover leading to a slightly lower 17-19 mm increase in yield (Sahin and Hall, 1996). Effects on peak flows differ with basin size, \%forest cover lost, degree of forest soil compaction, mechanism generating peak flows, and the presence of roads (Keenan and Kimmins, 1993; Thomas and Megahan, 1998; Jones, 2000). In general, studies have found a greater effect of deforestation on lowmagnitude storm events, increasing the frequency and volume of moderate flows in late summer and fall, when soil moisture is normally depleted (Buttle and Metcalfe, 2000), rather than increasing peak annual flows. However, Verry et al. (1983) documented a significant increase in both 2-year and 10-year event peak flows of 1.5-2.5 times following clearcutting of upland aspen in north central Minnesota. Our study did not cover a sufficient range of years to evaluate effects on 10-year event peak flows, but did demonstrate an increase in peak flow frequency and duration for moderate flow events in third-order streams with low mature forest.

\subsection{Evidence for hydrological thresholds}

Thresholds of response for fraction mature forest that we determined (51-64\%) were similar to those expected, based on empirical relationships between snowmelt peak flows and percent watershed clearcut within the past 15 years; Verry (1986) observed a slight decrease in peak flows as \% recent clearcutting increased from 0 to $40 \%$, then a strong increase in peak flows above $60 \%$ recent clearcuts (Verry, 1986). In the Pacific Northwest, the loss of forest cover beyond $65 \%$ of the watershed with conversion to low-density development or hobby farms results in an increase in $Q_{2}$ flows to levels consistent with pre-impact $Q_{10}$ levels, and an associated destabilization of channels with increased bank 
erosion (Booth et al., 2002). In contrast, our response thresholds of 18 and $23 \%$ for watershed storage were slightly higher than expected, as empirical relationships developed between 2-year peak flows and fraction watershed storage show exponential increases in peak flows below 5-10\% watershed storage (Detenbeck et al., 2000, Krug et al., 1992; Jacques and Lorenz, 1988). Our PC scores integrated several different flow and velocity metrics, some of which may be less sensitive to land-use and land-cover thresholds than are peak flows. In addition, tributaries to the western arm of Lake Superior include some regions of significant soil storage (Bayfield Peninsula), which may provide additional buffering capacity and shift the 'apparent' threshold upward.

\subsection{Ecological significance of landscape controls on flow regimes}

With a few exceptions, response thresholds for flow and velocity PC scores were similar to the range of those found for biological response thresholds. For example, in analyzing biological data from our study, Brazner et al. (2004) found that response thresholds identified by marked shifts in fish assemblage structure or function averaged $11 \%$ for watershed storage and $50 \%$ for watershed mature forest cover based on piecewise regression analysis. Previous analysis of flow regimes for Minnesota and Wisconsin suggests that the range of variation encountered in flow stability and peak flows is biologically significant, and can select for distinct functional groups within fish and invertebrate communities (Poff and Ward, 1989; Poff and Prestegaard, 1997).

Unlike analyses carried out over broader regions of the US, analysis of regional effects did not show strong evidence for distinct flow regimes that were geographically stable and coherent, but rather, flow regimes were significantly modified by local variations in depression storage and mature forest cover. It is possible that once hydrologic landscape units as described by Winter (2001) have been classified and refined through multivariate analysis, these could be associated with different flow regime types. This would allow prediction of flow regimes for unmonitored watersheds, as well as associated biological community traits and impacts of changing land-use.
There are trade-offs between conducting broadscale analyses of data from well-established gauging stations with long periods of record (e.g. $>20$ years) and refined rating curves vs. conducting regionalscale studies with a higher spatial intensity of flow sampling, but shorter period of record. In particular, indices of flow predictability will be influenced by the period of record examined, and even indices related to event magnitude will be influenced by year-to-year variation in climate. Although the accuracy and precision of flow metrics we calculated was less than it would be if we had access to long-term records from those same sites, our results were generally in agreement with studies conducted with longer periods of record. The spatial intensity of flow sampling that we implemented allowed us to make comparisons across watershed classes within welldefined regions to identify controlling factors operative at a finer scale, and to integrate these data with the results of intensive biological and water quality monitoring. Ideally, the two approaches would be combined.

\section{Summary}

Our study demonstrates that analysis of differences in seasonal flow regimes for even short periods of record can distinguish regional patterns related to hydrogeomorphology, watershed storage, and landuse. Many of the axes of variation for flow metrics we described for a short period of record at the regional scale are consistent with those determined from longer stream records collected across multiple ecoregions, although we cannot assess flood predictability with our short term records. Within an ecoregion, there is a high degree of redundancy in seasonal flow metrics for different magnitude events; from a practical viewpoint, event magnitude described probably will be limited by climatic regime during the period of record. Analysis of velocitybased metrics can identify streams with unique velocity regimes which could account for regional variation in some community types; more research in this area is needed. Overall, our results support the development and application of categorical flow-based classification schemes using thresholds of response related to land-use and land-cover. 
Development of these relationships should allow the prediction of flow regimes and impacts of changing land-use for ungauged watersheds.

\section{Acknowledgements}

We gratefully acknowledge the contributions of the following individuals for both field and lab support: E. Alexander, D. Beattie, C. Birschbach, R. Blazevik, J. Brazner, J. D’Lugosz, S. Fabbro, K. Gislason, T. Jicha, A. Lemke, T. Schlick, D. Tanner, J. Thompson, and L. Fredrick. Geographic Information
System support was provided by D. Fruehling, L. Jagger, and S. Stark (OAO), and M. Starry (Computer Sciences Corporation). We thank Mark Pearson and Trent Schade for providing helpful reviews of an earlier version of this manuscript. The information in this document has been funded wholly by the US Environmental Protection Agency. It has been subjected to review by the National Health and Environmental Effects Research Laboratory and approved for publication. Approval does not signify that the contents reflect the views of the Agency, nor does mention of trade names or commercial products constitute endorsement or recommendation for use.

\section{Appendix A}

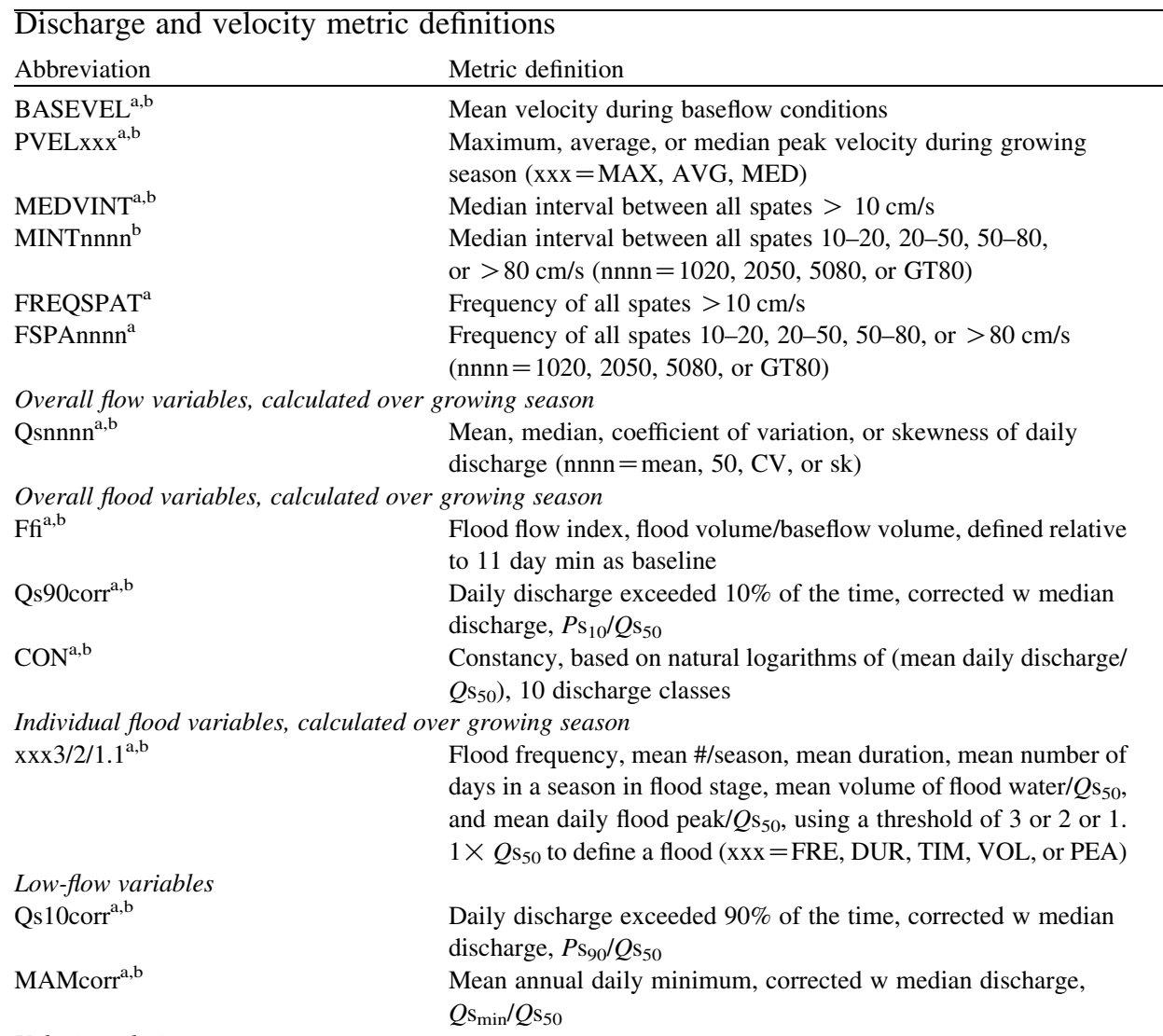

Velocity relative to stream power $\operatorname{FRxxxx}^{\mathrm{a}, \mathrm{b}}$
Reference

Clausen and Biggs (1997)

Clausen and Biggs (1997)

Clausen and Biggs (1997)

Clausen and Biggs (1997)

Clausen and Biggs (1997)

Clausen and Biggs (1997)

Clausen and Biggs (1997)

Quinn and Hickey (1994)
Average daily Froude number during baseflow periods or average peak Froude number during floods $(\mathrm{xxxx}=$ base, avpk) 


\begin{tabular}{|c|c|c|}
\hline Abbreviation & Metric definition & Reference \\
\hline ISVxxxx ${ }^{a, b}$ & $\begin{array}{l}\text { Average daily Inferred Shear Velocity during baseflow periods or } \\
\text { average peak Inferred Shear Velocity during floods }\left(>3 \times Q \mathrm{~s}_{50} \text {, }\right. \\
\mathrm{xxxx}=\text { base, avpk) }\end{array}$ & $\begin{array}{l}\text { (continued on next page) } \\
\text { Quinn and Hickey (1994) }\end{array}$ \\
\hline \multicolumn{3}{|c|}{ Basin descriptors } \\
\hline QperAREA $^{\mathrm{a}, \mathrm{b}}$ & Mean annual discharge $(\mathrm{mm} / \mathrm{yr})$, size scalar for streams & Poff (1996) \\
\hline LQSMEAN & Grand mean discharge of the log10-transformed discharge & Poff (1996) \\
\hline \multicolumn{3}{|c|}{ Overall flow variability } \\
\hline $\mathrm{C}$ & $\begin{array}{l}\text { Constancy, based on } \mathrm{Ln}+1 \text { of mean daily discharge } / Q \mathrm{~s}_{\text {mean }} \text {, } \\
10 \text { flow classes, note different scaling factor than above }\end{array}$ & Poff (1996) \\
\hline \multicolumn{3}{|c|}{ Pattern of the flood regime } \\
\hline FLODxxxx & $\begin{array}{l}\text { Flood frequency per season, median interval (days) between } \\
\text { floods, mean duration of floods, maximum number of days in } 1997 \\
\text { during which no floods occurred, maximum number of days } \\
\text { common to } 1997 \text { and } 1998 \text { with no floods, median day of water } \\
\text { year (Oct 1=1) on which floods have occurred, using flood } \\
\text { threshold at bankfull discharge (xxxx=INT, DUR, FRE7, FREE, } \\
\text { TIME) }\end{array}$ & Poff (1996) \\
\hline FLOD60D & $\begin{array}{l}\text { Index of flood predictability, maximum proportion of total flood } \\
\text { days occurring in any } 60 \text { day interval, modified from Poff and } \\
\text { Ward (1989), who analyzed maximum proportion of total floods/ } \\
60 \text { day period }\end{array}$ & Poff and Ward (1989) \\
\hline \multicolumn{3}{|c|}{ Distribution of discharge values } \\
\hline CVLF5 $^{\mathrm{a}, \mathrm{b}}$ & $\begin{array}{l}\text { Coefficient of variation of discharges with percentiles of 5-95 } \\
\text { in increments of } 5\end{array}$ & Richards (1990) \\
\hline $\mathrm{RnRm}^{\mathrm{a}, \mathrm{b}}$ & $\begin{array}{l}\text { Ratio of } n \text {th percentile to } m \text { th percentile discharges }(n / m=10 / 90 \text {, } \\
20 / 80 \text {, or } 25 / 75)\end{array}$ & Richards (1990) \\
\hline SptnS ${ }^{\mathrm{a}, \mathrm{b}}$ & $\begin{array}{l}.5 \text { spread }(75-25 \text { percentile/median discharge), } .6 \text { spread }(80-20 \\
\text { percentile/median discharge), or } .8 \text { spread, }(90-10 \text { percentile/ } \\
\text { median discharge; } n=5,6 \text {, or } 8)\end{array}$ & Richards (1990) \\
\hline
\end{tabular}

${ }^{a}$ Variable used in principal components analysis of second-order stream data.

${ }^{\mathrm{b}}$ Variable used in principal components analysis of third-order stream data.

\section{References}

Advanced Graphics Software, Inc.,1999. Slide-Write Plus for Windows, Version 5.01. Advanced Graphics Software, Encinitas, CA.

Biggs, B.J.F., Stevenson, R.J., Lowe, R.L., 1998a. A habitat matrix conceptual model for stream periphyton. Archiv fur Hydrobiologie 143, 21-56.

Biggs, B.J.F., Goring, D.G., Nikora, V.I., 1998b. Subsidy and stress responses of stream periphyton to gradients in water velocity as a function of community growth form. Journal of Phycology 34, 598-607.

Booth, D.B., Hartley, D., Jackson, R., 2002. Forest cover, impervious surface area, and the mitigation of stormwater impacts. Journal of the American Water Resources Association 38 (3), 835-845.

Brazner, J.C., Tanner, D.K., Detenbeck, N.E., Batterman, S.L., Stark, S.K., Jagger, L.A., Snarski, V.M., 2004. Landscape character and fish assemblage structure and function in western Lake Superior streams: general relationships and identification of thresholds. Environmental Management. 33, 855-875.

Breiman, L., Friedman, J.H., Olshen, R.A., Stone, C.J., 1984. Classification and Regression Trees. Wadsworth \& Brooks/Cole Advanced Books and Software, Monterey, CA.

Buttle, J.M., Metcalfe, R.A., 2000. Boreal forest disturbance and streamflow response, northeastern Ontario. Canadian Journal of Fisheries and Aquatic Sciences 57 (Suppl. 2), 5-18.

Castellarin, A., Burn, D.H., Brath, A., 2001. Assessing the effectiveness of hydrological similarity measures for flood frequency analysis. Journal of Hydrology 241, 270-285.

Clausen, B., Biggs, B.J.F., 1997. Relationships between benthic biota and hydrological indices in New Zealand streams. Freshwater Biology 38, 327-342.

Clausen, B., Biggs, B.J.F., 2000. Flow variables for ecological studies in temperate streams: groupings based on covariance. Journal of Hydrology 237, 184-197.

Cobb, D.G., Galloway, T.D., Flannagan, J.F., 1992. Effects of 
discharge and substrate stability on density and species composition of stream insects. Canadian Journal of Fisheries and Aquatic Sciences 49, 1788-1795.

Detenbeck, N.E., Batterman, S.L., Brady, V.J., Brazner, J.C., Snarski, V.M., Taylor, D.M., Thompson, J.A., Arthur, J.A., 2000. The western Lake Superior watershed framework: a test of geographically-dependent vs. geographically-independent, threshold-based watershed classification systems for ecological risk assessment. Environmental Toxicology and Chemistry 19, 1174-1181.

Detenbeck, N.E., Elonen, C.M., Taylor, D.L., Anderson, L.E., Jicha, T.M., Batterman, S.L., 2003. Effects of hydrogeomorphic region, watershed storage and mature forest on baseflow and snowmelt stream water quality in second-order Lake Superior Basin tributaries. Freshwater Biology 48 (5), 911-927.

Detenbeck, N.E., Elonen, C.M., Taylor, D.L., Anderson, L.E., Jicha, T.M., Batterman, S.L., 2004. Region, Landscape and scale effects on lake Superior tributary water quality. Journal of the American Water Resources Association. 40, 705-720.

Fetter, C.W., 1988. Applied hydrogeology, second ed. Merrill, Columbus, $\mathrm{OH}$.

Galea, G., Javelle, P., Chaputk, N., 2000. A discharge-durationfrequency model adapted for low flow. Journal of Water Science 13, 421-440.

Gan, K.C., McMahon, T.A., Finlayson, B.L., 1991. Analysis of periodicity in streamflow and rainfall data by Colwell's indices. Journal of Hydrology 123, 105-118.

Goforth, G.F., Heaney, J.P., Huber, W.C., 1983. Comparison of basin performance modeling techniques. Journal of Environmental Engineering 109 (5), 1082-1098.

Griffiths, G.A., Clausen, B., 1997. Streamflow recession in basins with multiple water storages. Journal of Hydrology 190, 60-74.

Hawkins, C.P., Norris, R.N., Gerritsen, J., Hughes, R.M., Jackson, S.K., Johnson, R.K., Stevenson, R.J., 2000. Evaluation of the use of landscape classifications for the prediction of freshwater biota: synthesis and recommendations. Journal of the North American Benthological Society 19, 541-556.

Heede, B.H., Rinne, J.N., 1990. Hydrodynamic and fluvial morphological processes: implications for fisheries management and research. North American Journal of Fisheries Management 10, 249-268.

Jacques, J.E., Lorenz, D.L., 1988. Techniques for estimating the magnitude and frequency of floods of ungauged streams in Minnesota. 87-4170, Water Resources Investigations Report. US Geological Survey, Washington, DC.

Jennings, M.E., Thomas Jr., W.O., Riggs, H.C., 1993. Nationwide Summary of US Geological Survey Regional Regression Equations for Estimating Magnitude and Frequency of Floods for Ungaged Sites, 1993. 94-4002. USGS Water Resources Investigations Report. Reston, VA, USA.

Jones, J.A., 2000. Hydrologic processes and peak discharge response to forest removal, regrowth, and roads in 10 small experimental basins, western Cascades, Oregon water Resources Research. 36 (9), 2621-2642.

Jowett, I.G., 1993. A method for objectively identifying pool, run, and riffle habitats from physical measurements. New Zealand Journal of Marine and Freshwater Research 27, 241-248.
Keenan, R.J., Kimmins, J.P., 1993. The ecological effects of clear cutting. Environmental Reviews 1, 121-144.

Keys Jr.., J.E., Carpenter, C.A., Hooks, S.L., Kownig, F.G., McNab, W.H., Russell, R.E., Smith, M.L., 1995. Ecological Units of the Eastern United States: First Approximation. USDA Forest Service.

Krug, W.R., Conger, D.H., Gebert, W.A., 1992. Flood-frequency characteristics of Wisconsin streams. 91-4128, US Geological Survey Water Resources Investigation Report. US Geological Survey, Madison, WI.

Magilligan, F.J., Graber, B.E., 1996. Hydroclimatological and geomorphic controls on the timing and spatial variability of floods in New England, USA. Journal of Hydrology 178, 159180.

McCuen, R.H., Hromadka II., T.V., 1988. Flood skew in hydrologic design on ungaged watersheds. Journal of Irrigation and Drainage Engineering 114 (2), 301-310.

Mckune, B., Mefford, M.J., 1999. Multivariate Analysis of Ecological Data, version 4.14. MjM Software, Gleneden Beach, OR.

Midwest Climate Center, 2000. Midwest Climate Center, Illinois State Water Survey, Champaign, IL.

Minnesota State Climatology Office. St Paul, MN. http://climate. umn.edu/

Moore, R.D., 1997. Storage-outflow modelling of streamflow recessions, with application to a shallow-soil forested catchment. Journal of Hydrology 198, 261-270.

Olcott, P.G., Ericson, D.W., Felsheim, P.E., Broussard, W.L., 1978. Water resources of the Lake Superior watershed, northeastern Minnesota., Hydrologic Investigations Atlas HA-582. US Geological Survey, Reston, VA.

Omernik, J.M., Gallant, A.L., 1988. Ecoregions of the upper Midwest states. EPA/600/3-88/037. US Environmental Protection Agency, Environmental Research Laboratory, Corvallis, OR.

Petras, I., 2001. ArcView Areal Rain Extension. http://gis.esri.com/ arcscripts/scripts.cfm.

Poff, N.L, 1992. Why disturbances can be predictable: a perspective on the definition of disturbance in streams. Journal of the North American Benthological Society 11, 86-92.

Poff, N.L., 1996. A hydrogeography of unregulated streams in the United States and an examination of scale-dependence in some hydrological descriptors. Freshwater Biology 36, 71-91.

Poff, N.L., 1997. Landscape filters and species traits: towards mechanistic understanding and prediction in stream ecology. Journal of the North American Benthological Society 16, 391409.

Poff, N.L., Allan, J.D., 1995. Functional organization of stream fish assemblages in relation to hydrologic variability. Ecology 76, 606-627.

Poff, N.L., Prestegaard, K.L., 1997. Utility of the physical habitat template as a predictor of lotic ecosystem invasibility by alien species. Report to US Environmental Protection Agency, MidContinent Ecology Division, Duluth, MN.

Poff, N.L., Ward, J.V., 1989. Implications of streamflow variability 
and predictability for lotic community structure: a regional analysis of streamflow patterns. Canadian Journal of Fisheries and Aquatic Sciences 46, 1805-1818.

Post, D.A., Jones, J.A., 2001. Hydrologic regimes of forested, mountainous, headwater basins in New Hampshire, North Carolina, Oregon, and Puerto Rico. Advanced Water Resources 24, 1195-1210.

Quinn, J.M., Hickey, C.W., 1994. Hydraulic parameters and benthic invertebrate distributions in two gravel-bed New Zealand rivers. Freshwater Biology 32, 489-500.

Richards, R.P., 1990. Measures of flow variability and a new flowbased classification of Great Lakes tributaries. Journal of Great Lakes Research 16, 53-70.

Richter, B.D., Baumgartner, J.V., Powell, J., Braun, D.P., 1996. A method for assessing hydrologic alteration within ecoystems. Conservation Biology 10, 1163-1174.

Roberts, J., 2000. Influence of physical and physiological characteristics of vegetation on their hydrological response. Hydrologic Processes 14, 2885-2901.

Sahin, V., Hall, M.J., 1996. The effects of afforestation and deforestation on water yields. Journal of Hydrology 178, 293 309.

SAS, 1990. SAS/STAT User's Guide, vol. 2, GLM-VARCOMP. Version 6, fourth ed. SAS Institute, Cary, NC.

SAS Institute, Inc., 1991. SAS System for Statistical Graphics, first ed. SAS Institute, Cary, NC.

Seaber, P.R., Kapinos, F.P., Knapp, G.L., 1987. Hydrologic Unit Maps: US Geological Survey Water-Supply Paper 22941987. $63 \mathrm{pp}$.

Simonson, T.D., Lyons, J., Kanehl, P.D., 1994. Quantifying fish habitat in streams: transect spacing, sample size, and a proposed framework. North American Journal of Fisheries Management 14, 607-615.
Smakhtin, V.Y., 2001. Low flow hydrology: a review. Journal of Hydrology 240, 147-186.

Smakhtin, V.Y., Toulouse, M., 1998. Relationships between lowflow characteristics of South African streams. Water SA 24, 107-112.

Sokal, R.R., Rohlf, F.J., 1995. Biometry, third ed. (W.H.) Freeman, San Francisco, CA.

Statzner, B., Higler, B., 1986. Stream hydraulics as a major determinant of benthic invertebrate zonation patterns. Freshwater Biology 16, 127-139.

Tasker, G.D., 1982. Comparing methods of hydrologic regionalization. Water Resources Bulletin 18 (6), 9665-9670.

Thomas, R.B., Megahan, W.F., 1998. Peak flow responses to clear-cutting and roads in small and large basins, western Cascades, Oregon: a second opinion. Water Resources Research 34, 3393-3403.

Verry, E.S., 1986. Forest harvesting and water: the Lake States experience. Water Resources Bulletin 22, 1039-1047.

Verry, E.S., Lewis, J.R., Brooks, K.N., 1983. Aspen clearcutting increases snowmelt and stormflow peaks in north central Minnesota. Water Resources Bulletin 19, 59-67.

Wadeson, R.A., Rowntree, K.M., 1998. Application of the hydraulic biotope concept to the classification of instream habitats. Aquatic Ecosystem Health and Management 1, 143-157.

Whitehead, P.G., Robinson, M., 1993. Experimental basin studiesan international and historical perspective of forest impacts. Journal of Hydrology 145, 217-230.

Wilkinson, L., 1999. Systat 9.0 Statistics I. SPSS, Inc., Chicago, IL. Winter, T.C., 2001. The concept of hydrologic landscapes. JAWRA 37, 335-350.

Wisconsin State Climatology Office, Madison, WI. http://www.aos. wisc.edu/ sco/. 